\title{
SISTEM PENGELOMPOKAN PESERTA DIDIK DI SEKOLAH DASAR NEGERI
}

\author{
M. Ghulaman Zakia \\ E-mail: Ghulamanzakia358@gmail.com \\ SDN Model Kota Malang \\ J1. Raya Tlogowaru No. 3 Kedungkandang Kota Malang
}

\begin{abstract}
The focus of this research is the base of students grouping, the type of students grouping, the way of students grouping, the positive and negative effect of students grouping, the problems of students grouping, and the way to resolve this problems. This research uses qualitative approach and use case studiesat SD Negeri Model Kota Malang. The result shows students grouping at this school uses the achievement, the characteristic, and the interest of students.
\end{abstract}

Keywords: grouping, students, Elementary School

\begin{abstract}
Abstrak: Fokus dari penelitian ini adalah dasar pengelompokan peserta didik, jenis pengelompokan peserta didik, cara pengelompokan peserta didik, dampak positif dan negatif pengelompokan peserta didik, kendala dalam pengelompokan peserta didik, dan cara mengatasi kendala pengelompokan peserta didik. Penelitian ini menggunakan pendekatan kulitatif jenis studi kasus, dengan lokasi penelitian di SD Negeri Model Kota Malang. Temuan penelitian menunjukkan pengelompokan peserta didik di sekolah itu menggunakan jenis prestasi, karakteristik, dan bakat minat peserta didik.
\end{abstract}

Kata kunci: Pengelompokan, Peserta didik, SD Negeri

Lembaga pendidikan yang memberikan dasar dalam pembentukan karakter peserta didik adalah sekolah dasar.Jenjang sekolah dasar di Indonesia dilaksanakan meliputi enam jenjang atau enam tingkatan, mulai dari kelas satu hingga kelas enam.Lembaga pendidikan yang memberikan dasar dalam pembentukan karakter peserta didik adalah sekolah dasar.Jenjang sekolah dasar di Indonesia dilaksanakan meliputi enam jenjang atau enam tingkatan, mulai dari kelas satu hingga kelas enam dan terbagi menjadi beberapa rombongan belajar dan kelompok.

Salah satu lembaga pendidikan sekolah dasar yang memiliki beberapa rombongan belajar di setiap jenjang kelas adalah SD Negeri Model.SD Negeri Model beralamatkan di Jalan Raya Tlogowaru nomor 3 Kedungkandang Kota Malang.Sekolah dasar ini merupakan sekolah dasar negeri yang memiliki rombongan belajar terbanyak di Kota Malang.Jumlah rombongan belajar di SD Negeri Model Kota Malang adalah 31 rombongan belajar dari keseluruhan jenjang, mulai dari jenjang kelas satu hingga jenjang kelas enam. Jumlah rombongan belajar pada setiap jenjang kelas di SD Negeri Model tidak sama. Jumlah rombongan belajar dari setiap jenjang kelas adalah sebagai berikut, kelas 1 terdiri dari 5 rombongan belajar, kelas 2 terdiri atas 7 rombongan belajar, kelas 3 terdiri atas 5 rombongan belajar, kelas 4 terdiri atas 5 rombongan belajar, kelas 5 terdiri atas 4 rombongan belajar, dan kelas 6 terdiri atas 5 rombongan belajar. Berdasarkan hasil penelitian awal yang dilakukan peneliti ditemukan bahwa pengelompokan peserta didik di SD Negeri Model ini juga di acak kembali setiap dua tahun sekali.

Peserta didik dalam suatu sekolah berperan sebagai sasaran pendidikan yang memiliki hak untuk mendapatkan pelayanan yang layak dari sekolah.Hal tersebut sejalan dengan penjelasan Prihatin (2011:3) bahwa peserta didik merupakan individu yang memiliki kepribadian, citacita, dan potensi diri tertentu, serta tidak boleh diperlakukan secara semena-mena. Menurut Nasihin dan Sururi (dalam Tim Dosen AP UPI 2009:205) menyatakan bahwa peserta didik merupakan individu yang mendapatkan pelayanan pendidikan sesuai dengan bakat, 
minat, dan kemampuannya agar memiliki perkembangan daya berpikir sehingga dapat menerima pembelajaran yang diberikan oleh pendidik kepadanya.Peserta didik merupakan sasaran utama dalam pelaksanaan programprogram sekolah.Setiap peserta didik memiliki persepsi terhadap program sekolah yang berbedabeda sesuai dengan keyakinan masing-masing. Menurut Heider (dalam Safitri dan Bafadal, 2007:2) persepsi individu dalam menanggapi stimulus yang datang dapat mempengaruhi tingkah laku yang dilakukannya, apakah individu tersebut akan melakukan sesuatu atau tidak melakukannya. Tingkah laku yang dilakukan individu tersebut tergantung pada kebutuhan dan motivasinya masing-masing.

Pengelompokan peserta didik adalah suatu cara sekolah untuk memberikan pelayanan yang maksimal kepada peserta didik. Menurut Imron (2012:97) pengelompokan atau grouping adalah suatu penempatan peserta didik sesuai dengan karakteristik-karakteristik yang ada pada peserta didik.Hal tersebut perlu dikelompokan, agar guru lebih mudah dalam memberikan perhatian atau pelayanan kepada peserta didik. Pengelompokan peserta didik juga sering disebut pengklasifikasian.Penjelasan tersebut diperkuat oleh penjelasan Nasihin dan Sururi (dalam Tim Dosen AP UPI, 2009:210-211) bahwa terdapat dua hal yang mendasari pengelompokan peserta didik.Hal yang pertama adalah fungsi integrasi, yaitu pengelompokan peserta didik berdasarkan kesamaan yang ada pada peserta didik. Kesamaan ini meliputi jenis kelamin, umur, dan sebagainya. Sedangkan hal lain yang mendasari pengelompokan peserta didik adalah fungsi perbedaan, yaitu pengelompokan peserta didik berdasarkan perbedaan yang ada pada peserta didik seperti bakat, minat, karakter dan kemampuan peserta didik.

Setiap sekolah memiliki kewenangan untuk memilih jenis pengelompokan yang sesuai dengan kemampuan yang dimilikinya. Menurut Regan (dalam Prihatin, 2011:72-74) terdapat tujuh jenis pengelompokan peserta didik, yaitu 1) SD tanpa tingkat (the noun grade elementary school) adalah pengelompokan peserta didik pada sekolah dasar tanpa ada jenjang kelas; 2) pengelompokan kelas rangkap (multi grade and multi age grouping) adalah sekolah dasar dengan sistem tingkat; 3) pengelompokan kemajuan rangkap (the dual progress plan) adalah pengelompokan untuk mengatasi perbedaan kemampuan pada peserta didik; 4) penempatan sekolompok peserta didik pada seorang guru (self combined classroom) adalah pengelompokan seperti halnya pada guru kelas; 5) pembelajaran beregu (team teaching) adalah pengelompokan peserta didik yang yang diberikan pembelajaran oleh guru dalam bentuk tim; 6) departementalisasi adalah pengelompokan peserta didik dengan guru hanya mengkhususkan dirinya pada satu bidang pelajaran; dan 7) pengelompokan berdasarkan kemampuan (ability grouping) adalah sistem pengelompokan peserta didik dengan menyesuaikan kemampuan peserta didik.

Cara pengelompokan juga sangat beragam sesuai dengan tujuan pengelompokan tersebut.Menurut Syarkawi (2011) pengelompokan peserta didik dapat dilaksanakan melalui proses tes. Hal tersebut ditujukan di madrasah ibtidaiyah di Lumajang.Jenis tes yang dilaksanakan meliputi tes minat, tes bakat, dan tes kemampuan intelegensi. Berdasarkan hasil tes tersebut akan diperoleh potensipotensi yang dimiliki oleh setiap peserta didik dan potensi tersebut dijadikan sebagai kriteria pengelompokan peserta didik. Pengelompokan tersebut dilakukan untuk meningkatkan efektifitas dan efesiensi pembelajaran di madrasah, serta untuk memudahkan pembimbimbingan peserta didik sesuai dengan potensi yang dimilikinya.

Keefektifan cara pengelompokan dapat dilihat dari hasil atau pengaruh program pengelompokan peserta didik tersebut terhadap perkembangan daya berpikir anak. Oleh karena itu perlu dilaksanakan evaluasi program pengelompokan.Menurut Hamalik (2011:260261) desain evaluasi mencakup beberapa komponen yaitu: 1) penentuan garis besar evaluasi yang meliputi identifikasi tingkat pembuatan keputusan dan penetapan lokasi, fokus, waktu dan komposisi alternatifnya; 2) pengumpulan informasi yang meliputi penentuan sumber informasi, penentuan instrumen dan metode pengumpulan data, prosedur sampling, dan spesifikasi kondisi dan skedul informasi; 3) organisasi informasi yang meliputi spesifikasi format informasi dan spesifikasi alat pengkodeannya; 4) analisis informasi yaitu pengolahan informasi yang telah didapatkan terkait kendala-kendala yang dijumpai; 5) 
pelaporan informasi yang meliputi penentuan pihak penerima evaluasi, alat penyedia informasi, format laporan informasi, dan jadwal pelaporan; dan 6) administrasi evaluasi yang meliputi rangkuman jadwal evaluasi, penentuan kendalakendala yang dihadapi oleh informan, cara untuk memecahkan maslah atau kendala yang ada, dan penilaian keefektifan pemecahan masalah yang ditentukan. Sedangkan menurut Hamdani (2011:298) evaluasi pendidikan merupakan suatu proses yang sistematis untuk mengukur tingkat kemajuan yang telah dicapai peserta didik, ditinjau dari norma tujuan dan norma kelompok. Evaluasi pendidikan juga merupakan suatu proses yang sistematis dalam menentukan apakah siswa mengalami kemajuan belajar atau tidak.

Tujuan dari penelitian ini adalah untuk mendeskripsikan dasar pengelompokan peserta didik, jenis pengelompokan peserta didik, cara pengelompokan peserta didik, dampak positif dan negatif pengelompokan peserta didik, kendala dalam pengelompokan peserta didik, serta cara mengatasi kendala pengelompokan peserta didik yang dilaksanakan di SD Negeri Model Kota Malang.

\section{METODE}

Pendekatan yang digunakan dalam penelitian ini adalah pendekatan kualitatif.Pendekatan kualitatif digunakan untuk menemukan sesuatu dalam pengamatan peneliti di lapangan. Jenis penelitian ini menggunakan penelitian studi kasus untuk meneliti fenomena yang terjadi di lapangan.Penelitian studi kasus adalah suatu metode penelitian yang memusatkan pada suatu kasus dan mengkajinya secara mendalam. Lokasi penelitian ini adalah SD Negeri Model Kota Malang.Sekolah ini merupakan salah satu SD Negeri unggulan di Kota Malang.SD Negeri Model memiliki beberapa prestasi baik dalam bidang akademik maupun non akademik dan memiliki 31 rombongan belajar.

Pelaksanaan penelitian ini peneliti datang langsung ke SD Negeri Model Kota Malang sebagai objek penelitian, dan melakukan pengambilan data kepada para informan dengan menerapakan teknik-teknik pengambilan data pada penelitian kualitatif. Peneliti dalam melaksanakan penelitian ini juga melaksanakan magang di SD Negeri Model Kota Malang. Cara tersebut dilaksanakan oleh peneliti karena peneliti ingin mengetahui peristiwa-peristiwa yang terjadi sehari-hari di lokasi penelitian yang terkait dengan pengelompokan rombongan belajar peserta didik.

Informan pada penelitian ini adalah Kepala SD Negeri Model Kota Malang, sebagai penentu kebijakan di sekolah termasuk penentuan sistem pengelompokan rombongan belajar peserta didik; Waka Kesiswaan SD Negeri Model Kota Malang yang merupakan bidang yang menangani urusan yang terkait dengan peserta didik; Waka Kurikulum SD Negeri Model Kota Malang yang merupakan bidang yang berkaitan dengan kegiatan pembelajaran di sekolah; Guru SD Negeri Model Kota Malang yang merupakan komponen pendidikan yang mengetahui prestasi belajar peserta didik secara langsung; dan Peserta Didik SD Negeri Model Kota Malang yang merupakan sasaran dari pelaksanaan pengelompokan peserta didik. Sumber tambahan pada penelitian ini berupa dokumen atau sumber tertulis. Sumber tersebut dapat berupa foto-foto dan juga arsip surat-surat penting.

Teknik dalam pengumpulan data pada penelitian ini antara lain: teknik wawancara, teknik observasi, dan teknik dokumentasi. Sedangkan analisis dat penelitian ini meliputi: 1) reduksi data merupakan langkah memilih temuan yang pokok dan sesuai dengan fokus penelitian; 2) display data adalah penyajian hasil reduksi data dalam bentuk narasi singkat, bagan, serta tabel atau flowchart; 3) verifikasi data dari display data yang telah dibuat kepada informan, selain itu peneliti juga membandingkan hasil display data dengan sumber data lain yang akurat. Sedangkan pengecekan keabsahan data penelitian ini menggunakan derajat kepercayaan atau kredibilitas (credibility), keteralihan (transferability), ketergantungan (dependability), dan kepastian (confirmability).

\section{HASIL}

Pengelompokan peserta didik di SD Negeri Model Kota Malang didasari atas dua hal, yaitu persamaan dan perbedaan peserta didik. Persamaan pada peserta didik mendorong untuk mengelompokan peserta didik pada satu kelompok yang sama, dan perbedaan peserta didik menjadikan peserta didik pada kelompok yang berbeda. Persamaan-persamaan tersebut 
dirinci dengan menentukan hal-hal yang ada pada peserta didik, misalkan minat, usia, prestasi, dan hal-hal lain, sehingga peserta didik yang memiliki persamaan akan bertempat di kelompok yang sama. Pengelompokan tersebut bertujuan untuk memberikan pelayanan yang baik kepada peserta didik.Sedangkan perbedaan peserta didik dapat dirinci menjadi beberapa hal meliputi prestasi peserta didik, jenis kelamin, sikap, dan minat peserta didik.Peserta didik dibedakan dalam beberapa kelompok tersebut bertujuan untuk memudahkan peserta didik dalam mengembangkan pengetahuannya.

Secara umum pengelompokan peserta didik di SD Negeri Model dalam sistem rombongan belajar dilaksanakan secara merata. Sehingga dalam satu rombongan belajar terdiri dari beragam bakat dan minat peserta didik, beragam prestasi belajar peserta didik, dan beragam pula karakter peserta didik. Jenis pengelompokan di SD Negeri Model Kota Malang selain pengelompokan dalam sistem rombongan belajar juga dikelompokan secara khusus, yaitu meliputi: 1) Prestasi peserta didik SD Negeri Model Kota Malang;2) karakteristik peserta didik SD Negeri Model Kota Malang;dan 3) bakat dan minat peserta didik SD Negeri Model Kota Malang.

Pengelompokan prestasi ini dilaksanakan dengan mengelompokan peserta didik yang memiliki prestasi tinggi.Setelah dikelompokan peserta didik tersebut mendapat pembinaan khusus sebagai persiapan lomba yang hendak diikuti oleh para peserta didik tersebut.Sedangkan bakat dan minat peserta didik dikelompokan pada kegiatan ekstrakurikuler.Dengan demikian di SD Negeri Model Kota Malang terdapat beberapa jenis ekstra kurikuler sesuai bakat minat peserta didik.Pengelompokan peserta didik di SD Negeri Model Kota Malang juga menggunakan jenis karakteristik atau sikap peserta didik. Pengelompokan ini untuk memudahkan pembinaan peserta didik.Pembinaan tersebut bertujuan untuk merubah karakter peserta didik yang sebelumnya kurang baik menjadi lebih baik.

Cara pengelompokan peserta didik di SD Negeri Model Kota Malang menggunakan cara tes dan observasi. Tes yang dilaksanakan tidak dilaksanakan khusus, namun diintegrasikan dalam ujian sekolah atau ujian kenaian kelas. Sedangkan observasi dilaksanakan khusus untuk mengetahui bakat dan minat yang dimiliki oleh peserta didik.

Pengelompokan peserta didik memiliki dampak positif terkait perilaku peserta didik dan motivasi belajar peserta didik.Selain kepada peserta didik, pengelompokan tersebut juga memiliki dampak positif bagi guru.Dampak terhadap guru adalah berupa meningkatnya kemampuan serta pengalaman mengajar guru. Sehingga guru dapat mengajar di berbagai jenjang di sekolah dasar.Dampak positif dari pengelompokan peserta didik juga dapat membentuk kepercaya dirian peserta didik SD Negeri Model Kota Malang.

Sedangkan dampak negatif pengelompokan peserta didik juga berkaitan dengan peserta didik dan juga guru. Namun seluruh dampak negatif tersebut sejauh ini tidak mengganggu proses pembelajaran secara lama, hanya pada periode awal saja. Oleh karena guru sebagai penanggung jawab yang utama pada proses pembelajaran harus dapat mengkondisikan kelasnya sekondusif dan senyaman mungkin agar peserta didik merasa betah mengikuti kegiatan pembelajaran di kelas.

Kendala yang ditemui dalam pengelompokan peserta didik adalah terkait dengan adapatasi peserta didik.Peserta didik membutuhkan watu untuk beradaptasi dengan teman kelas barunya. Selain itu juga ditemukan peserta didik yang memiliki kecenderungan tidak cocok dengan salah satu peserta didik sehingga terjadi perselesihan. Kendala lain yaitu terkait kevalidan data yang diberikan guru dan juga waktu yang diperlukan dalam penghimpunan data dan juga pemrosesan data.

Selain kendala yang terkait langsung dengan peserta didik juga terdapat kendala lain yang berkaitan dengan bidang administrasi. Kendala yang dihadapi dalam pengelompokan peserta didik bidang administrasi adalah masalah pendataan peserta didik seperti halnya penulisan nama yang benar pada peserta didik. Penulisan nama tersebut dijadikan acuan dalam penyusunan nomor ujian. Kendala lainnya terkait pendataan peserta didik pada buku induk peserta didik. Hal tersebut dikarenakan dalam satu jenjang saja peserta didik dapat menyebar dan juga mengakibatkan menyebarnya data peserta didik pada beberapa buku induk.

Cara sekolah dalam mengatasi kendala pengelompokan peserta didik tidak dapat terlepas 
dari peran guru. Guru memiliki peran yang sangat penting dalam mengatasi permasalahan adaptasi peserta didik. Guru kelas harus berusaha membuat peserta didik di dalam kelasnya merasa nyaman. Oleh karena itu jika terjadi perselisihan guru juga harus dapat bertindak sebagai penengah dan juga memahami kemauan dari setiap peserta didik.

Sedangkan cara mengatasi perbedaan penulisan nama peserta didik dilakukan dengan cara mngambil data peserta didik pada satu sumber, sehingga seluruh guru kelas memiliki sumber data yang sama yaitu di koordinator kurikulum. Sedangkan cara mengatasi kendala terkait pengisian buku induk peserta didik dilaksanakan dengan cara penjadwalan, sehingga guru kelas memilikijadwaltersendiri.Pelaksanaan cara-cara tersebut diharapkan dapat mengurangi kendala-kendala dalam pengelompokan peserta didik khususnya pada bidang administrasi.

\section{PEMBAHASAN}

Pengelompokan peserta didik di SD Negeri Model Kota Malang dilaksanakan dalam rangka untuk memudahkan pihak sekolah terutama guru dalam memberikan pelayan kepada peserta didik.Hal itu dikarenakan peserta didik diartikan sebagai komponen utama dari sekolah yang menjadi sasaran dari tujuan pendidikan. Peserta didik di SD Negeri Model Kota Malang diharapkan selalu mendapat pelayanan prima dari sekolah.Sekolah selalu mengedepankan hal-hal yang berkaitan dengan terciptanya peserta didik dengan kompetensi unggul.

Temuan yang telah dipaparkan diatas sejalan dengan penjelasan ahli mengenai peserta didik Nasihin dan Sururi (dalam Tim Dosen AP UPI 2009:205) menyatakan bahwa peserta didik merupakan individu yang mendapatkan pelayanan pendidikan sesuai dengan bakat, minat, dan kemampuannya agar memiliki perkembangan daya berpikir sehingga dapat menerima pembelajaran yang diberikan oleh pendidik kepadanya. Peserta didik adalah sasaran dalam pelaksanaan pembelajaran.

Pengelompokan peserta didik di SD Negeri Model Kota Malang menggunakan prestasi peserta didik, hal ini dilaksanakan dengan mengelompokan peserta didik yang memiliki prestasi tinggi.Setelah dikelompokan peserta didik tersebut mendapat pembinaan khusus sebagai persiapan lomba yang hendak diikuti oleh para peserta didik tersebut.Selain prestasi peserta didik, bakat dan minat peserta didik di SD Negeri Model Kota Malang juga diperhatikan.Bakat dan minat peserta didik tersebut dikelompokan pada kegiatan ekstrakurikuler.Dengan demikian di SD Negeri Model Kota Malang terdapat beberapa jenis ekstra kurikuler sesuai bakat minat peserta didik. Jenis pengelompokan yang lain yaitu pengelompokan peserta didik menggunakan jenis karakteristik atau sikap peserta didik. Pengelompokan ini untuk memudahkan pembinaan peserta didik.Pembinaan tersebut bertujuan untuk merubah karakter peserta didik yang sebelumnya kurang baik menjadi lebih baik.

Hal tersebut sejalan dengan teori yang menyebutnya sebagai ability grouping Regan (dalam Prihatin, 2011:72-74) terdapat tujuh jenis pengelompokan peserta didik, yaitu: 1) SD tanpa tingkat (the noun grade elementary school) adalah pengelompokan peserta didik pada sekolah dasar tanpa ada jenjang kelas; 2) pengelompokan kelas rangkap (multi grade and multi age grouping) adalah sekolah dasar dengan sistem tingkat; 3) pengelompokan kemajuan rangkap (the dual progress plan) adalah pengelompokan untuk mengatasi perbedaan kemampuan pada peserta didik; 4) penempatan sekolompok peserta didik pada seorang guru (self combined classroom) adalah pengelompokan seperti halnya pada guru kelas; 5) pembelajaran beregu (team teaching) adalah pengelompokan peserta didik yang yang diberikan pembelajaran oleh guru dalam bentuk tim; 6) departementalisasi adalah pengelompokan peserta didik dengan guru hanya mengkhususkan dirinya pada satu bidang pelajaran; dan 7) pengelompokan berdasarkan kemampuan (ability grouping) adalah sistem pengelompokan peserta didik dengan menyesuaikan kemampuan peserta didik.

Sebelum dilaksanakan pengelompokan Koordinator Kurikulum di SD Negeri Model Kota Malang akan membagian lembar isian kepada seluruh guru kelas. Lembar isian tersebut berisi nama peserta didik, kategori prestasi belajar meliputi high, middle, dan low. Serta terdapat kolom keterangan yang berisi sikap atau karakteristik dari peserta didik.Prestasi belajar peserta didik tersebut diperoleh guru dari keseharian peserta didik dan hasil nilai peserta didik.Sedangkan sikap peserta didik diperoleh 
dari pengamatan masing-masing guru kelas. Pengelompokan tersebut sebagaimana pendapat Imron (2012:97), bukan bermaksud untuk mengotak-kotakkan peserta didik, melainkan justru bermaksud membantu mereka agar dapat berkembang seoptimal mungkin.

Nilai peserta didik dijadikan dasar dalam penggolongan kategori high, midle, dan low. Nilai tersebut diperoleh melalui tes atau ujian yang telah dilaksanakan oleh guru yang diintegrasikan dalam ujian sekolah. Temuan tersebut sesuai dengan paparan ahli Syarkawi (2011) pengelompokan peserta didik dapat dilaksanakan melalui proses tes. Hal tersebut ditujukan di madrasah ibtidaiyah di Lumajang. Jenis tes yang dilaksanakan meliputi tes minat, tes bakat, dan tes kemampuan intelegensi. Berdasarkan hasil tes tersebut akan diperoleh potensi-potensi yang dimiliki oleh setiap peserta didik dan potensi tersebut dijadikan sebagai kriteria pengelompokan peserta didik.

SD Negeri Model Kota Malang dalam meminimalisasi dampak negatif dalam pengelompokan peserta didik adalah dengan melakukan rapat koordinasi dengan guru-guru kelas yang bersangkutan sebagai narasumber. Sehingga dampak positif yang ada dapat dimaksimalkan, dan dampak negatifnya diminimalkan.Pelaksanaan tersebut sejalan dengan teori tentang langkah evaluasi yang dipaparkan oleh Hamalik (2011:258-259) evaluasi pendidikan dapat dilakukan melalui beberapa langkah yang di kelompokan kembali menjadi beberapa evaluasi pada sub-sub bagian kerja. Langkah pertama adalah evaluasi kebutuhan dan feasibility yaitu evaluasi yang bertujuan untuk merumuskan dan menetapkan strategi-strategi yang akan digunakan dalam pelaksanaan program pendidikan. Langkah kedua yaitu evaluasi masukan (input) merupakan proses dalam meperoleh informasi yang akurat dari narasumber-narasumber yang bersangkutan dengan program pendidikan. Langkah ketiga adalah evaluasi proses yaitu sistem pengelolaan data atau informasi yang telah didapatkan dari narasumber. Pengelolaan data ini bertujuan untuk memecahkan masalah-masalah yang ditemukan. Langkah keempat adalah evaluasi produk yaitu langkah yang berkaitan dengan pengukuran hasil yang dicapai pada program pendidikan, dan untuk memecahkan kendala-kendala yang mengurangi tingkat kualitas produk pendidikan.

Kendala-kendala pengelompokan peserta didik di SD Negeri Model Kota Malang ditemukan melalui rapat evaluasi yang dilaksanakan setiap akhir tahun pelajaran. Hal tersebut didukung teori yang dipaparkan oleh Hamdani (2011:298) evaluasi pendidikan merupakan suatu proses yang sistematis untuk mengukur tingkat kemajuan yang telah dicapai peserta didik, ditinjau dari norma tujuan dan norma kelompok. Evaluasi pendidikan juga merupakan suatu proses yang sistematis dalam menentukan apakah siswa mengalami kemajuan belajar atau tidak. Kegiatan evaluasi pendidikan keseluruhannya mencakup program-program yang telah dilaksanakan suatu lembaga pendidikan untuk meningkatkan mutu pembelajaran terhadap peserta didik.

Berdasarkan temuan penelitian yang telah dipaparkan, kendala di SD Negeri Model dalam pengelompokan peserta didik tidak bersifat permanen. Semua kendala tersebut dapat langsung diketahui melalui rapat kordinasi yang dilaksanakan.Sehingga dapat langsung diselesaikan, dan juga dapat dijadikan sebagai dasar dari program pengelompokan peserta didik di tahun berikutnya.

Cara pemecahan masalah atau kendala pengelompokan peserta didik di SD Negeri Model Kota Malang melalui rapat koordinasi atau rapat yang dilaksanakan dengan beberapa tahapan, tahapan tersebut yaitu penentuan topik evaluasi yaitu terkait kendala-kendala yang telah dipaparkan di atas, pengumpulan informasi dari narasumber yaitu guru kelas dan koordinator kurikulum, serta yang terakhir adalah penentuan keputusan pemecahan kendala yang dituliskan dalam notulen rapat SD Negeri Model Kota Malang. Sehingga dapat ditemukan cara untuk mengatasi kendala di atas adalah menekankan kepada guru kelas untuk membantu peserta didik yang kesulitan beradaptasi di kelas, sehingga peserta didik tersebut lebih betah di kelas. Sedangkan terkait dengan pengumpulan data cara mengatasinya adalah dengan menerapkan dead line waktu kepada guru kelas dalam pengumpulan data peserta didik.

Paparan data di atas didukung oleh teori yang terkait dengan desain evaluasi yang dipaparkan oleh Hamalik (2011:260-261) desain evaluasi mencakup beberapa komponen yaitu: 1) penentuan garis besar evaluasi yang meliputi 
identifikasi tingkat pembuatan keputusan dan penetapan lokasi, fokus, waktu dan komposisi alternatifnya; 2) pengumpulan informasi yang meliputi penentuan sumber informasi, penentuan instrument dan metode pengumpulan data, prosedur sampling, dan spesifikasi kondisi dan skedul informasi; 3) organisasi informasi yang meliputi spseifikasi format informasi dan spesifikasi alat pengkodeannya; 4) analisis informasi yaitu pengolahan informasi yang telah didapatkan terkait kendala-kendala yang dijumpai; 5) pelaporan informasi yang meliputi penentuan pihak penerima evaluasi, alat penyedia informasi, format laporan informasi, dan jadwal pelaporan; dan 6) administrasi evaluasi yang meliputi rangkuman jadwal evaluasi, penentuan kendala-kendala yang dihadapi oleh informan, cara untuk memecahkan masalah atau kendala yang ada, dan penilaian keefektifan pemecahan masalah yang ditentukan.

\section{KESIMPULAN DAN SARAN}

\section{Kesimpulan}

Dasar pengelompokan peserta didik di SD Negeri Model Kota Malang juga memperhatikan persamaan pada peserta didik. Selain persamaan peserta didik, perbedaan peserta didik di SD Negeri Model Kota Malang juga dijadikan dasar dalam pengelompokan sebagai pembeda antara satu kelompok dengan kelompok yang lain.

Jenis pengelompokan peserta didik di SD Negeri Model Kota Malang pada saat ini menerapkan jenis pengelompokan merata atau heterogen. Jenis pengelompokan di SD Negeri Model Kota Malang selain pengelompokan dalam sistem rombongan belajar juga dikelompokan secara khusus, yaitu meliputi: prestasi peserta didik SD Negeri Model Kota Malang, karakteristik peserta didik SD Negeri Model Kota Malang, serta bakat dan minat peserta didik SD Negeri Model Kota Malang.

Cara pengelompokan peserta didik di SD Negeri Model Kota Malang menggunakan cara tes dan observasi. Tes yang dilaksanakan tidak dilaksanakan khusus, namun diintegrasikan dalam ujian sekolah atau ujian kenaikan kelas. Sedangkan observasi dilaksanakan khusus untuk mengetahui bakat dan minat yang dimiliki oleh peserta didik.Pengelompokan peserta didik di SD Negeri Model Kota Malang juga memiliki beberapa dampak. Dampak tersebut meliputi dampak positif dan dampak negatif. Dampak positif dan negatif tersebut dapat diketahui melalui proses evaluasi setiap akhir tahun ajaran.

Pelaksanaan pengelompokan peserta didik di SD Negeri Model Kota Malang juga masih mengalami beberapa kendala. Kendala-kendala tersebut dapat diketahui melalui proses evaluasi tahunan yang dilaksanakan oleh sekolah.Cara mengatasi kendala-kendala tersebut adalah dengan guru memberikan perhatian ekstra kepada peserta didik, petugas pengelompokan memberikan deadline (batasan waktu) bagi guru kelas dalam pengisian form peserta didik, dan pengisian buku induk dilakukan penjadwalan khusus bagi setiap jenjang.

\section{Saran}

Pelaksanaan pengelompokan peserta didik sebaiknya menerapkan berbagai jenis pengelompokan tidak hanya menggunakan tiga jenis pengelompokan.Dengan demikian kegiatan pembelajaran peserta didik di sekolah dapat lebih variatif, dan juga dapat mencegah kejenuhan peserta didik.Pelaksanaan evaluasi terhadap program pengelompokan peserta didik juga sebaiknya dapat dilaksanakan rutin minimal enam bulan sekali tidak hanya satu tahun sekali, agar lebih efektif.

\section{DAFTAR RUJUKAN}

Hamalik, O. 2011.Dasar-dasar Pengembangan Kurikulum. Bandung: Remaja Rosdakarya.

Hamdani. 2011. Strategi Belajar Mengajar. Bandung: Pustaka Setia.

Imron, A. 2012.Manajemen Peserta Didik Berbasis Sekolah. Jakarta: Bumi Aksara.

Prihatin, E. 2011.Manajemen Peserta Didik. Bandung: Alfabeta.

Safitri, E. dan Bafadal, I. 2007. Persepsi Guru tentang Keterampilan Manusiawi Kepala Sekolah dengan Motivasi Kerja Guru. Jurnal Manajemen Pendidikan, 20(1): 2.

Syarkawi. 2011. Pola Pengelompokan Siswa Baru: Study Kasus di Madrasah Ibtidaiyah Bustanuk Ulum Sumberanyar Rowokangkung Lumajang. (Online), (http://digilib.uinsby.ac.id/9270/), diakses 2 Februari 2016.

Tim Dosen Administrasi Pendidikan UPI. 2009. Manajemen Pendidikan. Bandung: Alfabeta. 